\title{
PENGEMBANGAN HYBRID LEARNING BERBASIS APLIKASI COMPUTER ASSITED TEST (CAT) PADA PROGRAM ARABIC PROFICIENCY TEST
}

\author{
Ibnu Rawandhy N. Hula ${ }^{1}$, Moh. Zulkifli Paputungan ${ }^{2}$, Ana Mariana ${ }^{3}$ \\ ${ }^{12}$ Institut Agama Islam Negeri Sultan Amai Gorontalo, ${ }^{3}$ Universitas \\ Muhammadiyah Gorontalo \\ Email: ibnurawandi@iaingorontalo.ac.id
}

\begin{abstract}
ABSTRAK
Penelitian ini bertujuan mengembangkan Hybrid Learning berbasis aplikasi Computer Assited Test (CAT) pada program Arabic Proficiency Test (APT). Metode yang digunakan adalah Research And Development dengan model rancangan instruksional ADDIE (Analyze, Design, Develop, Implement dan Evaluate), dengan tahapan pengembangan (concept, design, material collecting, assembly, testing dan distribution). Hasil penelitian menunjukkan bahwa pengembangan Hybrid Learning berbasis aplikasi CAT dapat digunakan pada program Arabic Proficiency Test (APT) yang memuat tiga tes kompetensi bahasa, (istima, tarakib dan Qira'ah) serta memenuhi beberapa aspek; 1) Self Instructional, 2) Self Instructional, 3) Self Contained, 4) Standalone, 5) User Friendly, serta 6) Adaptif terhadap perkembangan teknologi. Hasil uji coba aplikasi CAT-APT pada kelompok terbatas diperoleh skor 80 (baik) s/d 88 (sangat baik), pada uji validasi media skor diperoleh 80 (baik) s/d 86 (sangat baik), uji validasi pemograman serta skor 80 (baik) s/d 88 (sangat baik), sedangkan uji coba pada tester, skor pretest belum sampai ke tingkat advance, sedangkan pada posttest diperoleh 9 tester yang mencapai skor advance.
\end{abstract}

Kata Kunci: Hybrid Learning, Computer Assited, Arabic Proficiency Test.

\begin{abstract}
This study aims to develop Hybrid Learning based on the Computer Assisted Test (CAT) application in the Arabic Proficiency Test (APT) program.The method used was Research and Development with the ADDIE instructional design model (Analyze, Design, Develop, Implement and Evaluate), with development stages (concept, design, material collecting, assembly, testing and distribution). The results showed that the development of Hybrid Learning based on CAT application can be used in the Arabic Proficiency Test (APT) program which contains three language competency tests, (istima, tarakib and Qira'ah) and fulfills several aspects; 1) Self Instructional, 2) Self Instructional, 3) Self Contained, 4) Standalone, 5) User Friendly, and 6) Adaptive to technological developments. The results of the CAT-APT application trial in a limited group obtained a score of 80 (good) to 88 (very good), in the media validation test the score was 80 (good) to 86 (very good), the programming validation test and a score of 80 (good) to 88 (very good), while in the testing on the tester, the pretest score had not yet reached the advanced level, while in the posttest there were 9 testers who reached the advanced score.
\end{abstract}

Keywords: Hybrid Learning, Computer Assisted, Arabic Proficiency Test. 


\section{PENDAHULUAN}

Pembelajaran dengan model hybrid learning di era 4.0 tidak bisa dihindari, pesatnya perkembangan teknologi serta munculnya kejadian luar biasa berupa Coronavirus Disease-2019 (COVID-19), telah berdampak pada pembatasan interaksi sosial, serta tertutupnya akses dan layanan pendidikan bagi masyarakat pada semua jenjang pendidikan. Dengan kondisi itu, lembaga-lembaga pendidikan termasuk pergurun tinggi juga dituntut untuk meramu dan memformat model pembelajaran yang sesuai dengan kebutuhan dan kondisi kekinian, yang simple, praktis, berbasis aplikasi teknologi dan mudah diakses baik secara online maupun offline, dengan tanpa mengurangi kualitas dan mutu pendidikan. Atas dasar kualitas, kecepatan dan kepraktisan itu pula, ujian tes bahasa Arab di perguruan tinggi telah berupaya menggeser model ujian konvensional ke arah komputerisasi berbasis pengembangan aplikasi yang compatible.

Kaitannya dengan hal itu, pengembangan aplikasi berbantukan computer system pada hakekatnya merupakan bagian dari Hybrid Learning, yakni "model pembelajaran yang dirancang untuk memadukan antara pembelajaran tatap muka dengan teknologi komputer dan internet" " ${ }^{1}$ artinya bahwa Hybrid Learning adalah pengintegrasian model pembelajaran dari tradisional ke arah system e-learning berbantukan sarana computer dan aplikasi tertentu.

Salah satu aplikasi yang saat ini sementara dikembangkan oleh Pusat Bahasa IAIN Sultan Amai Gorontalo untuk menjembatani layanan tes bahasa Arab pada program Arabic Proficiency Test (disingkat APT) ${ }^{2}$ adalah computer assisted test (disingkat CAT). Computer Assisted Test ${ }^{3}$ digunakan sebagai sarana evaluasi untuk mengukur pengetahuan dengan cara mengambil data peserta ujian yang memenuhi syarat dan menyimpan hasil ujian peserta dalam database induk. Di samping itu aplikasi ini banyak digunakan untuk ujian seleksi yang bertujuan menciptakan hasil ujian yang transparan, objektiv, akuntabel dan efisien, ${ }^{4}$. Mengingat ujian konvensional dengan menggunakan Lembar Jawaban Komputer (LJK), sangat rentan dengan kecurangan, kebocoran dan praktik-praktik spoil system, ${ }^{5}$. Atas dasar itu aplikasi ini dipandang aman, praktis dan mudah dalam

${ }^{1}$ Disa Hediansah and Herman Surjono, "Hybrid Learning Development to Improve Teacher Learning Management," JKTP: Jurnal Kajian Teknologi Pendidikan 3, no. 1 (2020): 1-9, https://doi.org/10.17977/um038v3i12019p001.

${ }^{2}$ Katrien Vanpee and Dan Soneson, "Arabic Proficiency Improvement Through a Culture of Assessment," in Foreign Language Proficiency in Higher Education (Springer, 2019), 197-216.

${ }^{3}$ Akbar Bahari, "Computer-Assisted Language Proficiency Assessment Tools and Strategies," Open Learning: The Journal of Open, Distance and e-Learning, 2020, 1-27.

${ }^{4} J$ ona Bungaran Basuki Sinaga, "Opini Peserta Seleksi Calon Aparatur Sipil Negara Terhadap Sistem Computer Assited Test (CAT)," MSDA, Manajemen Sumber Daya Aparatur 3, no. 1 (2019): 63-76, https://doi.org/https://doi.org/10.33701/jmsda.v7i1.1143.

${ }^{5}$ Fauzi Hafizh Rahardi et al., "Spoil System Sebagai Tantangan Penyelenggaraan Pemerintahan Di Era Digitalisasi," Prosiding Simposium Nasional "Tantangan Penyelenggaraan 
pelaksanaan ujian/tes bahasa Arab berbantukan komputer yang berorientasi pada tiga tes yakni : istima', tarakib dan qira'ah, ${ }^{6}$.

Perangkat lunak Computer Assisted Test (CAT) jika mengacu pada model ISO 9126 mestinya memenuhi empat hal yakni 1) functionality, 2) reliability, 3) usability, dan 4) efficiency. ${ }^{7}$ Atas dasar itu, CAT pada program Arabic Proficiency Test berdasarkan fungsinya dapat dikembangkan untuk mengetahui kemampuan individual tester tentang tiga komponen bahasa, ${ }^{8}$ yang hasilnya (skor) dapat diketahui secara langsung setelah selesai menjawab soal. Sedangkan dilihat dari bentuknya, CAT pada program Arabic Proficiency Test (APT) adalah bentuk tes yang tidak dimaksudkan untuk menguji komptensi bahasa (tester) secara umum seperti tes halnya pada program TOEFL dan TOAFL (Test of Arabic as a Foreign Language) yang bertujuan untuk mengukur kemahiran Bahasa. Dalam sistem evaluasi bahasa Arab, ${ }^{9}$ term Arabic Proficiency Test, dikenal dengan istilah seperti ikhtibar kafa'ah, dan ikhtibar ijadah, oleh karena itu bentuk tes pada TOEFL dan TOAFL merupakan bagian test profisiency bahasa yang bertujuan untuk meningkatkan standar mutu lulusan secara akurat dan jelas, sehingga tingkat kemampuan tester dapat diukur secara pasti dan terstandarisasi. Perlu diketahui pula bahwa pembeda tes profisiensi bahasa antara TOEFL dan TOAFL adalah terletak pada aspek konten dan muatan soalnya yang mengangkat masalah Islamic Studies seperti ilmu kalam, tafsir, hadits, fiqhi, sehingga substansi tes tidak melulu pada aspek bahasa. ${ }^{10}$ Selain meningkatkan kemampuan bahasa TOAFL, juga bisa juga meningkatkan kualitas Pendidikan Bahasa Arab di perguruan tinggi. ${ }^{11}$ Meski realitasnya, test TOAFL masih digunakan secara terbatas dan sebatas prasyarat untuk mahasiswa pascasarjana mengakhiri studi dan

Pemerintahan Di Era Revolusi Indusri 4.O" 0, no. 0 (2020): 1378-1401, https://doi.org/https://doi.org/10.22219/PSNIP.Vol0.No0.II|1378-1401.

${ }^{6}$ Wahyudi Buska, Yogia Prihartini, and Nur Hasnah, "Analysis of Students' Arabic Proficiency for Vocabulary Mastery in State Islamic Junior High School in Muaro Jambi," INNOVATIO: Journal for Religious Innovation Studies 18, no. 1 (2018): 51-62, https://doi.org/10.30631/innovatio.v18i1.40.

${ }^{7}$ Khusnul Khotimah, "Pengembangan Prototipe Computer Assisted Test (Cat) Menggunakan Arsitektur Model View Controller Pada Badan Kepegawaian Negara," Jurnal Teknologi 8, no. 2 (2016): 53, https://doi.org/10.24853/jurtek.8.2.53-60.

${ }^{8}$ Nur Toifah, Evaluasi Dan Statistika Pembelajaran Bahasa Arab, Literasi Nusantara, 1st ed., vol. 53 (Malang: Literasi Nusantara, 2019).

"Ubaid Ridho, "Evaluasi Dalam Pembelajaran Bahasa Arab," An Nabighoh Jurnal Pendidikan Dan Pembelajaran Bahasa Arab 20, no. 01 (2018): 19, https://doi.org/10.32332/annabighoh.v20i01.1124.

${ }^{10}$ Muhbib Abdul Wahab, "Pengembangan Tes Bahasa Arab Standar Di Indonesia," Journal of Chemical Information and Modeling 53, no. 9 (2013): 1689-99.

${ }^{11}$ Mohamad Muhajir and Mohamad Naim Madjid, "The Importance of TOAFL in Improving the Language Skills of Arabic Language Education of Sixth Semester Students at Universitas Muhammadiyah Yogyakarta" 518, no. ICoSIHESS 2020 (2021): 253-57, https://doi.org/10.2991/assehr.k.210120.132. 
mahasiswa jurusan kebahasaan yang memiliki mata kuliah terkait dengan evaluasi dan tes bahasa.

Penelitian yang mengkaji tentang variable Hybrid Learning, Computer Assisted Test (CAT) dan Proficiency Test sudah banyak dilakukan, diantaranya: 1) Designing and modeling of a multi-agent adaptive learning system (MAALS) using incremental hybrid case-based reasoning $(I H C B R)^{12}$. Penelitian lebih diorientasikan pada system pembelajaran adaptif yang telah dikembangkan berdasarkan sistem bimbingan untuk mereduksi beban kognitif. Demikian pula penelitian yang dilakukan oleh Wang dan kawan-kawan tentang "An innovative preschool education method based on computer multimedia technology" Penelitian ini lebih fokus pada upaya mengembangkan metode pendidikan prasekolah yang inovatif berbasis teknologi multimedia komputer melalui Rain Classroom (RC), dengan hasil penelitian sebagian besar siswa dapat menerima mode pengajaran ini dan mode ini dapat meningkatkan minat belajar dan kemampuan komprehensif.

Penelitian tentang CAT sebagaimana yang dilakukan oleh Rahardin, Rokhmawati dan Brata, tentang: "Perancangan User Experience Aplikasi Computer Assisted Test (CAT) berbasis Website menggunakan Metode GoalDirected Design pada Badan Kepegawaian Daerah Kabupaten Lumajang" menyimpulkan bahwa UEQ pada tampilan peserta ujian menghasilkan kategori excellent pada skala attractiveness, efficiency, stimulation, dan novelty serta mendapatkan kategori good pada skala perspicuity dan dependability. Sedangkan pada tampilan panitia ujian menghasilkan kategori excellent pada keenam skala dari UEQ. Dari hasil tersebut dapat disimpulkan aplikasi CAT BKD baik tampilan untuk peserta ujian dan panitia ujian memberikan presepsi yang baik bagi pengguna. ${ }^{14}$

Adapun penelitian yang terkait dengan Proficiency Test, seperti yang dilakukan oleh Ahsanuddin dan Qodri “Analisis hasil TOAFL Mahasiswa Jurusan

12 El Ghouch Nihad, Kouissi Mohamed, and En Naimi El Mokhtar, "Designing and Modeling of a Multi-Agent Adaptive Learning System (MAALS) Using Incremental Hybrid CaseBased Reasoning (IHCBR)," International Journal of Electrical and Computer Engineering 10, no. 2 (2020): 1980-92, https://doi.org/10.11591/ijece.v10i2.pp1980-1992.

${ }^{13}$ Xiaoyue Wang, Han Sun, and Lixin Li, "An Innovative Preschool Education Method Based on Computer Multimedia Technology," International Journal of Emerging Technologies in Learning 14, no. 14 (2019): 57-68, https://doi.org/10.3991/ijet.v14i14.10714.

${ }^{14}$ Riekko Rahmat Rahardian, Retno Indah Rokhmawati, and Komang Candra Brata, "Perancangan User Experience Aplikasi Computer Assisted Test ( CAT ) Berbasis Website Menggunakan Metode Goal-Directed Design Pada Badan Kepegawaian Daerah Kabupaten Lumajang," Jurnal Pengembangan Teknologi Informasi Dan Ilmu Komputer 3, no. 7 (2019): 6486-94. 
Sastra Arab Fakultas Sastra Universitas Negeri Malang” 15, "Arabic Language Test in the Perspective of Competency-Based Curriculum for Students of Madrasah Aliyah Negeri 3 Malang " ${ }^{16}$ pada hakekatnya penelitian ini lebih fokus kepada Analisis hasil tes dan pendeskripsian butir soal UAS bahasa Arab sesuai kurikulum KBK yang tidak berorientasi pada penelitian Research and Development.

Dengan demikian maka penelitian ini dipandang penting untuk dilakukan, karena memiliki tingkat kebaruan pada aspek pengembangan aplikasi yang diformat dalam bentuk program Arabic Prociency Test (APT), sehingga dapat digunakan secara mandiri (self instructional), sesuai kebutuhan (self contained), dapat dioperasikan secara independen (standalone), mudah dioperasikan (user friendly), serta adaptif terhadap perkembangan teknologi.

Realitas di lapangan juga menunjukkan bahwa program Arabic Prociency Test yang meng-upgrade model TOAFL ${ }^{17}$ belum banyak tersaji seperti soal-soal TOEFL pada umumnya. Disamping itu TOAFL yang dilaksanakan di beberapa Perguruan Tinggi Keislaman Negeri (PTKIN) pemanfaatannya lebih diorientasikan pada internal masing-masing lembaga Bahasa, sehingga mendorong UPT Pusat Bahasa IAIN Sultan Amai untuk melakukan hal yang sama dalam rangka menunjang layanan tes Bahasa dan bisa diakses baik secara online maupun offline.

\section{METODE PENELITIAN}

Jenis penelitian ini menggunakan pendekatan Research and Development $(R \& d)$, yaitu aktivitas riset dasar untuk mendapatkan informasi kebutuhan pengguna (needs assessment), kemudian dilanjutkan dengan (development) Borg dan Gall menjelaskan bahwa $R \& D$ is a process used to develop and validate educational product, ${ }^{18}$ Artinya penelitian dan pengembangan bertujuan untuk mengembangkan dan menghasilkan produk penelitian yang valid melalui proses atau langkah yang bersifat siklik dan berulang-ulang seperti pengujian di

\footnotetext{
${ }^{15}$ Mohammad Ahsanuddin, "Jurusan Sastra Arab Fakultas Sastra," in Prosiding KONASBARA (Mal: KONASBARA, 2016), 304-9.

${ }^{16}$ Muhammad Qodri, “Arabic Language Test in the Perspective of Competency- Based Curriculum for Students of Madrasah Aliyah Negeri 3 Malang” 2, no. 2 (2019): 115-34, https://doi.org/https://doi.org/10.22219/jiz.v2i2.10003.

${ }^{17}$ Ahmad Syamsul Ma'arif, "Sighah Ikhtibarat Al-'Arabiyyah Fi Dui Al-Ikhtibar Al-Mutqn (TOAFL)," Jurnal Al Bayan 9, no. 2 (2017): 161-73, https://doi.org/https://doi.org/10.24042/albayan.v9i2.2233.

${ }^{18}$ Meredith Damien Gall, Walter R Borg, and Joyce P Gall. Educational Research: An Introduction. Longman Publishing, (1996: 10-24)
} 
lapangan, revisi produk hingga akhirnya menghasilkan produk yang sesuai dengan tujuan yang telah ditetapkan. ${ }^{19}$.

Dalam aspek pengembangan $C A T$, peneliti menggunakan model rancangan instruksional ADDIE (Analyze, Design, Develop, Implement dan Evaluate), ${ }^{20}$.



Gambar 1. Model ADDIE Piskurich

Untuk pengembangan hybrid lerning peneliti merujuk tahapan pengembangan mutimedia yang dirancang oleh Luther yang terdiri dari: (concept, design, material collecting, assembly, testing dan distribution), ${ }^{21}$ dimana setiap tahapannya tidak harus berurutan, tetapi dapat dikerjakan secara paralel dengan tahapan perencanaan (concept dan design), seperti siklus di bawah ini.

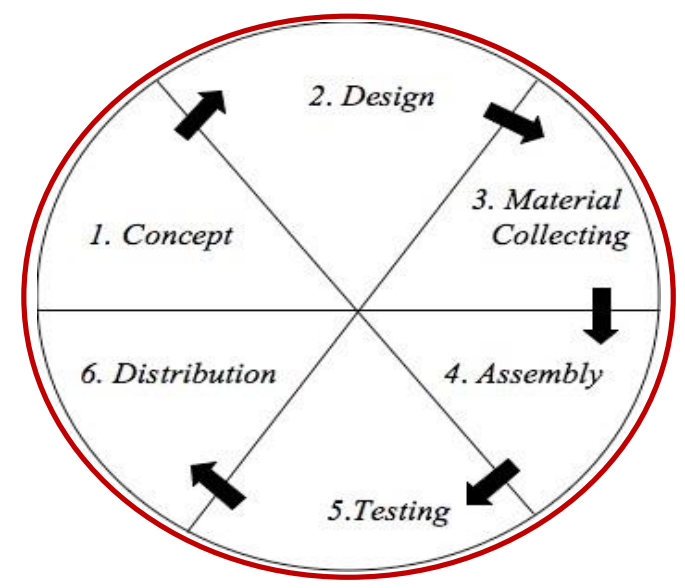

${ }^{19}$ Sitti Rabiah, "Penggunaan Metode Research and Development Dalam Penelitian Bahasa Indonesia Di Perguruan Tinggi," 2018.

${ }^{20}$ George M Piskurich, Rapid Instructional Design (Wiley Online Library, 2015), 62.

21 Arch C Luther, Authoring Interactive Multimedia (Academic Press Professional, Inc., 1994), 18. 
Gambar 2. Tahapan Development Multimedia Versi Luther

Rancang tahapan pembuatan CAT untuk Arabic Proficiency Test disajikan seperti di bawah ini:

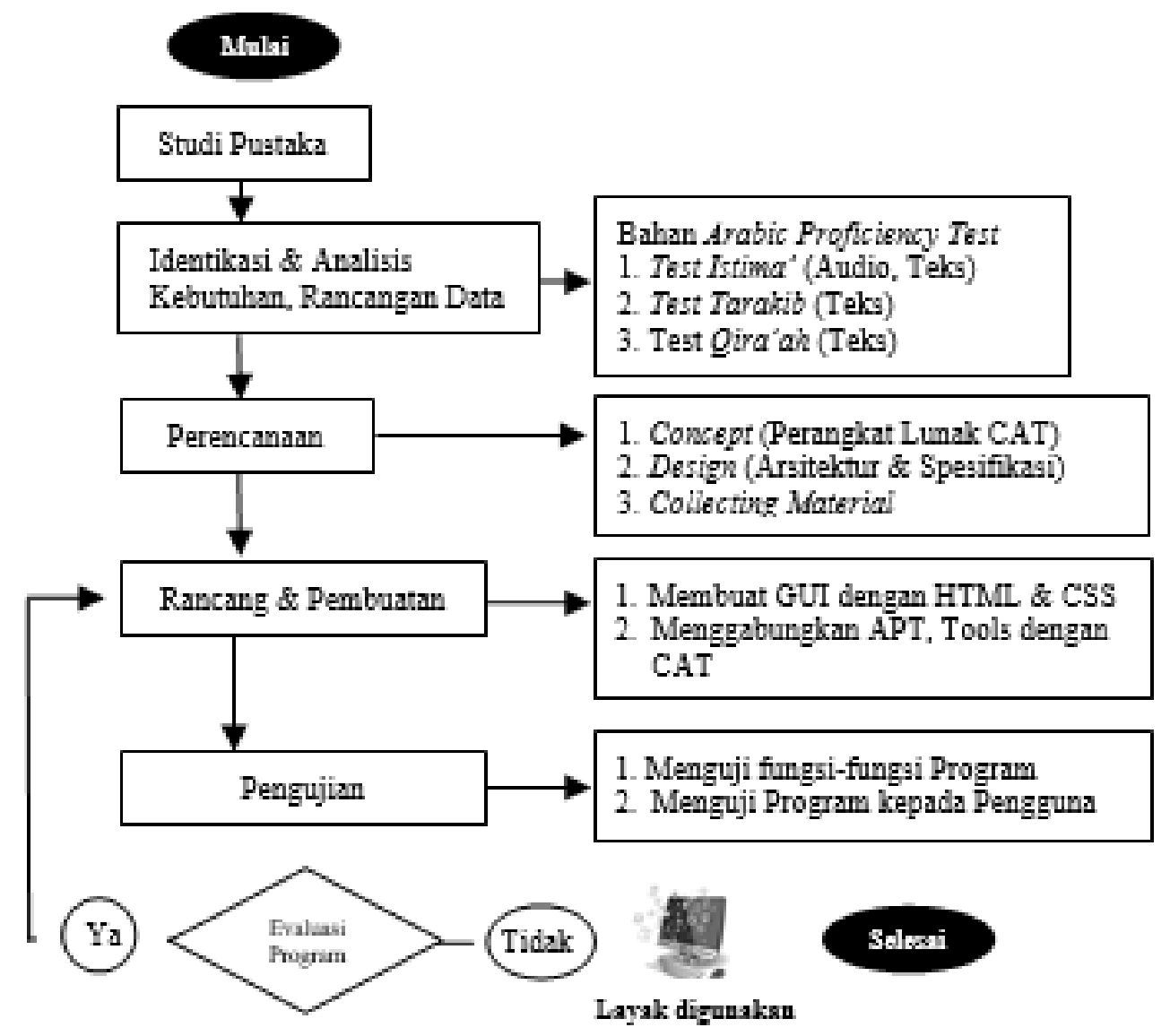

Gambar 3. Tahapan Development CAT

Untuk mengetahui apakah produk yang dihasilkan dari penelitian mencapai hasil seperti yang diinginkan, maka harus dilakukan pengukuran (measurement), penilaian (assessment), dan evaluasi (evaluation). Kegiatan evaluasi didahului oleh kegiatan penilaian, dari penilaian dilakukan kegiatan pengukuran untuk membandingkan hasil pengamatan dengan kriteria, sedangkan penilaian adalah kegiatan menafsirkan dan menggambarkan hasil pengukuran, dan kegiatan evaluasi bertujuan untuk mengetahui pencapaian hasil pembelajaran yang digambarkan dengan suatu angka/nilai dan perubahan perilaku dan respon pengguna. 
Data penelitian diperoleh dari tiga aspek; Pertama; populasi mahasiswa Jurusan Pendidikan Bahasa Arab sebanyak 276, ${ }^{22}$ dengan sampel 1 kelas berjumlah 20 Mahasiswa Kedua; Software expert yang berfungsi untuk menguji kebenaran materi Arabic Proficiency Test baik secara parsial maupun terintegrasi, yang hasilnya disesuaikan dengan menu dan sub-menu, isi dan konten soal, skor dan konversi nilai. Ketiga; Responden yang terdiri dari:1) Ahli media Hybrid Leaning; 2) Ahli materi APT; 3 ) Ahli Pemrograman CAT; 4) Pengguna, dengan instrumen ujicoba berupa kuesioner dengan skala perhitungan menggunakan skala Likert.

Tabel 1. Skor Skala Likert

\begin{tabular}{c|lc}
\hline No & Alternatif Jawaban & Skor \\
\hline 1 & Sangat Baik & 5 \\
\hline 2 & Baik & 4 \\
\hline 3. & Cukup & 3 \\
\hline 4. & Tidak Baik & 2 \\
\hline 5. & Sangat Tidak Baik & 1 \\
\hline
\end{tabular}

Interpretasi skor dihitung berdasarkan skor perolehan pada masing-masing aspek :

$\%$ Interpretasi Skor S. Skor Perolehan
S Skor Maksimum

Data yang akan diperoleh dari angket selanjutnya diukur dengan interpretasi skor sebagai berikut:

${ }^{22}$ PD-Dikti, "Data Mahasiswa Berdasarkan Pelaporan Aktifitas Mahasiswa Pada Tahun Ajaran Tersebut. Jika Tidak Sesuai, Perguruan Tinggi Diwajibkan Memperbaiki Pelaporannya Melalui Aplikasi PDDikti Feeder," Pangkalan Data Pendidikan TInggi, 2020, https://pddikti.kemdikbud.go.id/data_pt/QUJGOURBNEQtNUUyRS00MDg1LUIzODMtQjY4Qz dBNDIDM0VG. 
Tabel 2. Interpretasi Skor

\begin{tabular}{c|cc|}
\hline No & Presentasi & Interpretasi \\
\hline 1 & $0 \%-20 \%$ & Sangat Tidak Baik \\
\hline 2 & $21 \%-40 \%$ & Tidak Baik \\
\hline 3. & $41 \%-60 \%$ & Cukup \\
\hline 4. & $61 \%-80 \%$ & Baik \\
\hline 5. & $81 \%-100 \%$ & Sangat Baik \\
\hline
\end{tabular}

Pengembangan hybrid learning berbasis aplikasi CAT, peneliti menggunakan eksperimen kuasi dengan desain time series design yang hanya menggunakan satu kelas (eksperimen) saja, sehingga tidak memerlukan kelas kontrol. Teknisnya, sebelum diberikan perlakuan, kelas eksperimen terlebih dahulu diberikan pretest, selanjutnya diberi treatment (perlakuan) menggunakan computer assisted test (CAT) yang memuat materi APT, setelah itu diberi posttest.

Tabel 3. Pretest, Perlakuan dan Posstest

\begin{tabular}{ccc|}
\hline Pretest & Perlakuan & Posstest \\
\hline $\mathbf{0 1}$ & $\mathrm{X} 1$ & $\mathbf{0 2}$ \\
\hline $\mathbf{0 3}$ & $\mathrm{X} 2$ & $\mathbf{0 4}$ \\
\hline $\mathbf{0 5}$ & $\mathrm{X} 3$ & $\mathbf{0 6}$ \\
\hline $\begin{array}{l}\text { Keterangan } \\
01 / 03 / 05\end{array}$ & $=$ Nilai Pretest sebelum perlakuan \\
$\mathrm{X} 1 / \mathrm{X} 2 / \mathrm{X} 3$ & $=$ Perlakuan menggunakan CAT pada APT \\
$02 / 04 / 06$ & $=$ Nilai Posttest setelah Perlakuan
\end{tabular}




\section{HASIL DAN PEMBAHASAN \\ Pengembangan Produk}

Pada bagian ini peneliti akan mendeskripsikan hasil pengembangan produk adalah hybrid leaning berbasis CAT pada Arabic Proficiency Test dengan baik dengan model ADDIE maupun model Luther (CD-McATD), sebagai berikut:

\section{Tahap Analysis (Analisis)}

Tahap analisis merupakan langkah awal yang penting dan strategis untuk menentukan konsep (concept), rumusan dan tujuan penelitian ini. Tahap analisis dalam penelitian ini meliputi analisis kebutuhan, yaitu untuk mengetahui informasi mengenai pencapaian kompetensi bahasa Arab mahasiswa yang dapat diukur melalui pencapaian skor dengan program Arabic Proficiency Test. Dari hasil analisis tersebut diperoleh informasi bahwa Mahasiswa PBA IAIN Sultan Amai Gorontalo, belum pernah diuji kompetensi bahasanya melalui aplikasi CAT, sehingga konten soal istima', tarakib wa ta'birat dan qira'ah dipilih berdasarkan kategori rendah.

Berdasarkan fenomena di atas peneliti mengembangkan hybrid learning bahasa Arab berbasis CAT untuk mengatasi permasalahan rendahnya kompetensi mahasiswa PBA dalam tiga aspek yang disajikan pada program Arabic Proficiency Test.

\section{Tahap Design}

Pada tahap ini, peneliti mendesain dan merancang aplikasi CAT dengan mengacu pada standarisasi penyusunan paket soal program Arabic Proficiency Test dengan fitur yang disusun secara secara sistematis. Tahap design ini meliputi:

a. Kerangka paket soal Arabic Proficiency Test berbasis CAT.

Paket soal Arabic Proficiency Test berbasis CAT ini disusun dalam satu tampilan layar monitor komputer PC, dengan menu dan sub-menu. Pada menu soal APT terbagi menjadi tiga submenu yakni 1) Soal Istima' sebanyak 50 dengan format MP3, 2) Soal tarakib wa ta'birat sebanyak 40 dan 3) Soal qira'ah sebanyak 50 soal, sehingga total berjumlah 140 soal, ketiga jenis soal tersebut diunggah dalam aplikasi Computer Assisted Test (CAT). Menu lainnya adalah menu skor untuk mengetahui perolehan nilai untuk masing-masing soal, yang dihitung berdasarkan jumlah jawaban yang benar dari empat option objective test, kemudian menu konversi, adalah menu yang diperuntukkan untuk mengkonversi skor mentah menjadi skor akhir. 
Tabel 4. Skor dan Konversi APT

\begin{tabular}{l|l|c|c|c|c|}
\hline No & \multicolumn{1}{|c|}{ Bentuk } & \multicolumn{4}{|c|}{ Jumlah Jawaban Benar } \\
\hline & & Tinggi & Konversi & Rendah & Konversi \\
\hline 1 & Istima' & 50 & 68 & 1 & 25 \\
\hline 2 & Tarakib & 40 & 68 & 1 & 20 \\
\hline 3. & Qira'ah & 50 & 67 & 1 & 21 \\
\hline & $\begin{array}{l}(203: 3 \times 10)=677 \text { (Tinggi) } \\
(67: 3 \times 10)=220 \text { (Rendah) }\end{array}$ & $\mathbf{1 4 0}$ & $\mathbf{2 0 3}$ & $\mathbf{3}$ & $\mathbf{6 7}$ \\
\hline
\end{tabular}

Pada menu lainnya peneliti juga mencantumkan menu cetak sertifikat, sebagai bagian informasi akhir apakah tester dinyatakan lulus atau remedial/mengulang, sesuai dengan skor yang dipersyaratkan, misalnya untuk mahasiswa pascasarjana (450) mahasiswa jurusan PBA/Sastra Arab (500). Setelah diperoleh nilai konversi CAT-APT, selanjutnya diklasifikasi dengan empat peringkat yakni: Elementary (dasar), Low Intermediate (menengah bawah), High Intermediate (menengah bawah), dan Advance (mahir).

b. Material Collecting

Materi soal Arabic Proficiency Test selanjutnya diorganisasi ke dalam rancangan CAT dan untuk mengaksesnya dapat dilakukan melalui desain antarmuka secara Grafis (Graphical User Interface) yang ditulis (di-script) dan didesain dengan HTML dan CSS.

\section{Tahap Development}

Pada tahap ini aplikasi Computer Assisted Test (CAT) pada Arabic Proficiency Test, selanjutnya dikembangkan dengan tiga tahap, yakni : GUI (Graphical User Interface), Assembly dan validasi dan perbaikan produk.

a. Membuat antarmu secara Grafis (GUI)

Yaitu membuat antarmuka secara grafis atau Graphical User Interface dengan kode Hyper Text Markup Language, yaitu sebuah bahasa markup yang digunakan untuk membuat sebuah halaman website. CSS (Cascading Style Sheet) merupakan kumpulan kode-kode yang bertujuan untuk mengatur gaya tampilan atau layout halaman web supaya lebih menarik.

b. Assembly.

Yaitu menggabungkan tiga komponen soal Arabic Proficiency Test ke dalam CAT. 
c. Validasi dan Perbaikan Produk

Tahapan ini bertujuan untuk menguji CAT pada kelompok mahasiswa jurusan PBA, memvalidasinya melalui ahli materi, ahli pemrograman, kemudian uji coba terbatas pada mahasiswa, serta revisi produk.

Proses validasi merupakan proses penilaian ahli materi dan ahli pemrograman terhadap produk yang dikembangkan oleh peneliti. Penilaian ahli materi dilakukan dengan menggunakan angket sebagai alat penilaian otentik yang menjadi rujukan dalam perbaikan media pembelajaran yang dikembangkan. Lembar evaluasi berupa angket penilaian terhadap beberapa aspek yaitu: Aspek informasi pendahuluan, cara pengoperasian, cakupan materi APT, optional jawaban, sistem skor dan konversi. Penilaian Ahli Pemrograman menggunakan user acceptance testing.

Produk yang sudah jadi yaitu CAT pada APT, selanjutnya diujicobakan kepada kelompok mahasiswa jurusan PBA yang diperlakukan sebagai pengguna (user), ahli materi/ahli media pembelajaran dan ahli pemrograman. Untuk penguji produk perangkat lunaknya dilakukan oleh ahli pemograman, sedangkan hasil uji terbatas diberikan kepada user dan validasinya diorientasikan pada kesimpulan apakan produk pengembangan hybrid learning berbasis CAT pada APT, layak digunakan untuk menguji kompetensi bahasa Arab mahasiswa dan layanan tes bahasa Arab yang bersifat umum. Dalam tahap pengembangan ini, CAT-APT mengalami dua kali revisi hingga sampai pada produk yang digunakan untuk penelitian, yaitu:

a. Rancangan CAT-APT Pertama

Rancangan draft pertama dari CAT-APT yang dikembangkan dalam penelitian menurut masukan dari Ahli Pemrograman masih ada kekurangan, yaitu:

1) Tampilan menu CAT-APT pada beranda (Home), masih kaku, belum tertata dengan baik dan belum user friendly

2) Dokumen soal APT berbahasa Arab masih harus disesuaikan dengan font dan kompatibilitinya, termasuk penyesuaian file MP3 untuk materi istima', mengingat soal Arab memiliki diacritical marks yang berbeda-beda $^{23}$ dan ortografi yang beragam, sehingga tidak boleh salah. ${ }^{24}$

\footnotetext{
${ }^{23}$ Ibnu Rawandhy N Hula et al., "Diakritik Al-Quran Menurut Preferensi Abu Dawud," 'A Jamiy: Jurnal Bahasa Dan Sastra Arab 9, no. 2 (2020): 265-84, https://doi.org/http://dx.doi.org/10.31314/ajamiy.9.2.264-284.2020.

${ }^{24}$ Ibnu Rawandhy N Hula, "Preferensi Abu Dawud Sulaiman Bin Najjah Dalam Kaidah Rasm Al-Mushaf/Preference of Abu Dawud Sulaiman Bin Najjah In Rules of Rasm Al-Mushaf,” Diwan: Jurnal Bahasa Dan Sastra Arab 6, no. 2 (2020), https://doi.org/https://doi.org/10.24252/diwan.v6i2.13969.
} 
3) Tools skor dan konversi belum dapat dioperasikan, karena menggunakan rumus.

Tampilan login rancangan pertama disajikan dalam gambar berikut:

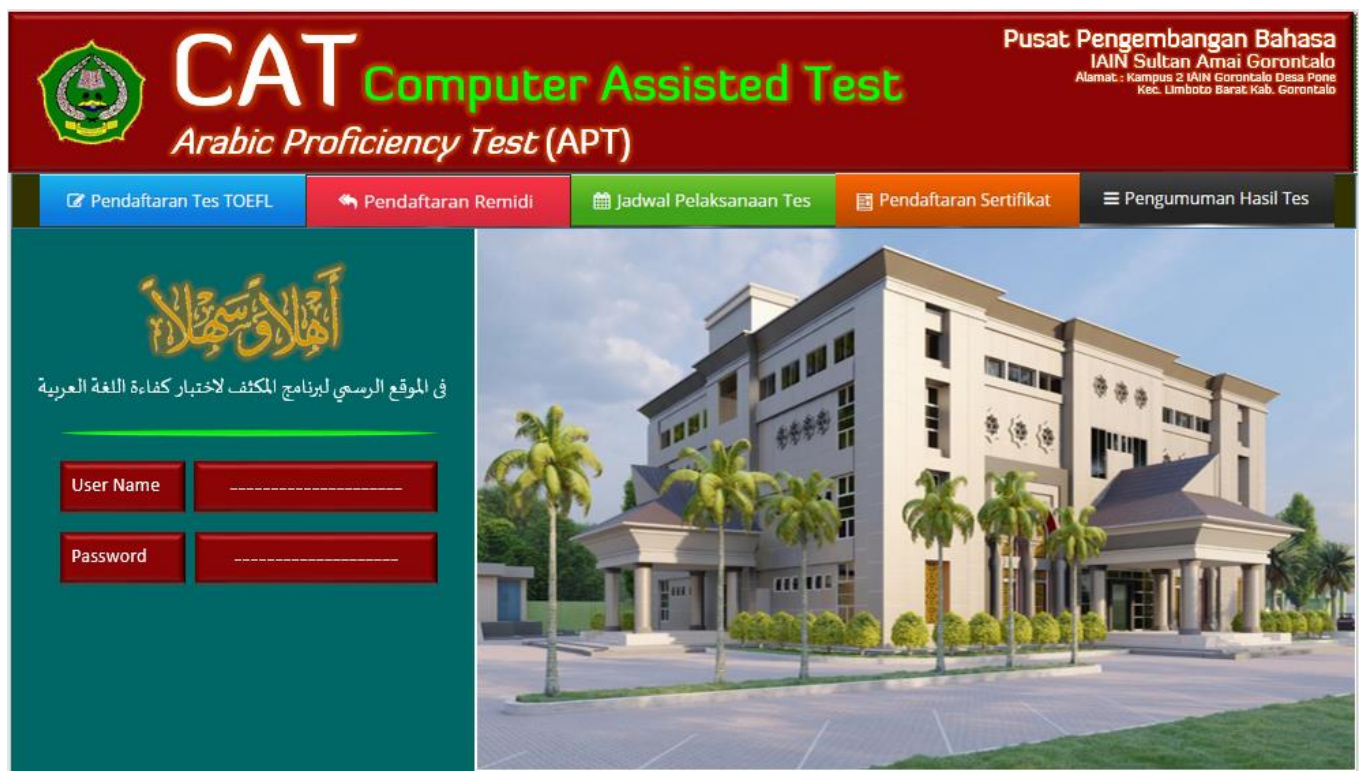

Gambar 4 : Menu Login

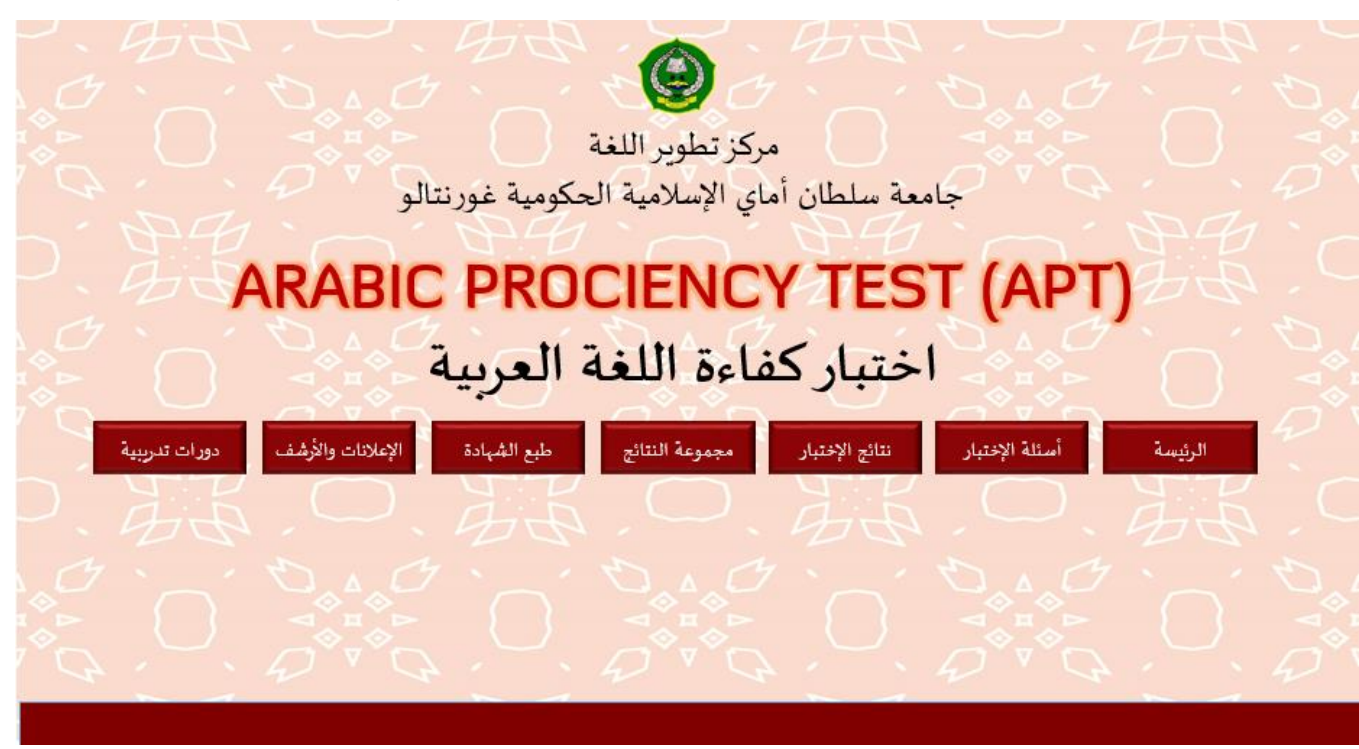

Gambar 5 : Menu Arabic Proficiency Test

b. Rancangan kedua (Final)

Merupakan rancangan final CAT-APT yang dikembangkan berdasarkan masukan dari ahli pemograman yang dioperasikan menggunakan web server dengan sistem operasi linux. Jadi web server merupakan perangkat lunak (software) dalam server difungsikan untuk menerima permintaan (request) berupa halaman web melalui protokol HTTP dan 
atau HTTPS dari client yang lebih dikenal dengan nama browser, kemudian mengirimkan kembali (respon) hasil permintaan tersebut ke dalam bentuk halaman-halaman web yang pada umumnya berbentuk dokumen HTML.

Dalam desain CAT-APT, penggunaan web server juga berfungsi mentransfer atau memindahkan berkas yang diminta oleh pengguna melalui protokol komunikasi tertentu, sehingga tampilan menu dan tools dapat berisi berbagai macam jenis berkas seperti gambar, video, teks, audio, file dan lain sebagainya yang dibutuhkan dalam penyusunan soal istima', tarakib dan qira'ah, seperti yang terlihat pada desain gambar 6 berikut:

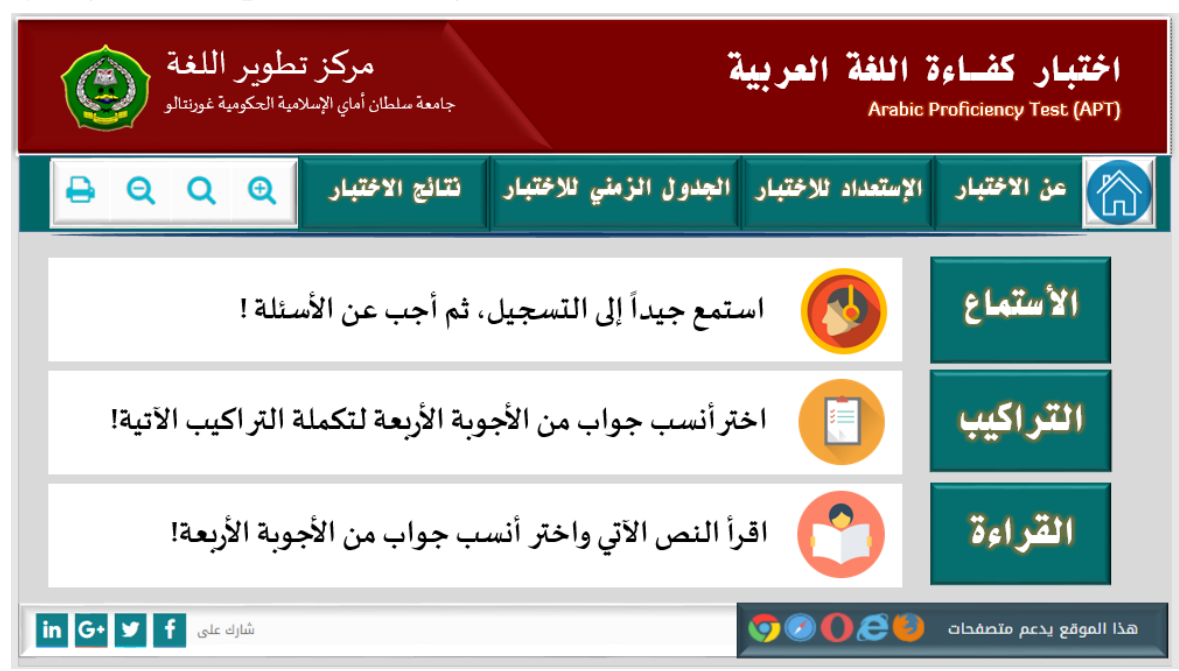

Gambar 6 : Tampilan Akhir menu APT

Pada menu dan submenu desain di atas, nampak jelas, bahwa soal Arabic Proficiency Test (APT) memiliki tiga menu soal yang terdiri dari istima', tarakib dan qira'ah, yang masing-masing telah diberi redaksi perintah berbahasa Arab 1) Istami' Jayyidan ila al-Tasjil, tsumma Ajib 'an al-As'ilah! untuk soal istima',2) Ikhtar Ansaba Jawabin min al-Ajwibah al-Arba'ah litakammulah al-Tarakib alAtiyah, dan 3) Iqra' al-Nash al-Atiy wakhtar Ansaba Jawabin min al-Ajwibah alAraba'ah. Ketiga bentuk soal APT tersebut, dikerjakan secara berurutan. Selanjutnya pada menu istima', jika diclick maka soal istima' akan muncul bersamaan dengan tombol play mp3, soal dan option, beserta jumlah soal dan durasi waktunya, seperti yang terlihat pada gambar 6 berikut. 


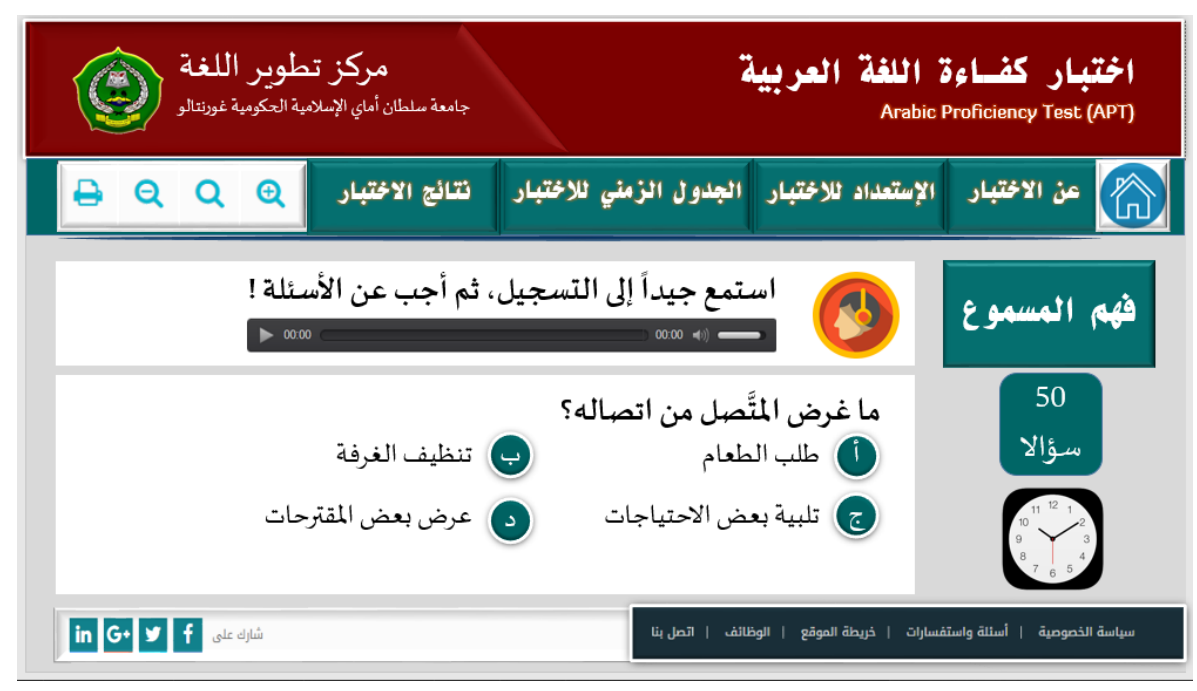

Gambar 6 : Tampilan Soal Istima’ APT

\section{Implementation}

Pada tahap ini, aplikasi CAT yang telah dikembangkan dalam program Arabic Proficiency Test (APT), kemudian dilakukan implementasi posttest untuk mengetahui pengaruh penggunaan CAT-APT tersebut terhadap kompetensi bahasa Arab yang dibuktikan dengan perolehan nilai/skor masing-masing. Implemetasi ini dilakukan pada 20 mahasiswa PBA semester V. Sebelum mahasiswa mengerjakan soal APT, laboran akan memberikan penjelasan menu dan submenu APT, kemudian dilanjutkan dengan pretest sebanyak tiga kali, dan diakhiri dengan posttest sebanyak satu kali.

\section{Evaluation}

Pada tahap ini, aplikasi CAT-APT, wajib dilakukan evaluasi untuk mengetahui hasil (outcome) proses pemanfaatannya serta kegunaan produk pengembangan hybrid learning yang telah diproduksi, beserta umpan balik (feedback) dan dampak (impact) yang timbul dari penggunaan CAT-APT ini. Pada tahap evaluasi ini, peneliti memberikan soal sebanyak 140, dengan konten masing-masing seperti pada tabel berikut:

Tabel 5. Konten Soal Arabic Proficiency Test (APT)

\begin{tabular}{lllll}
\hline No & Kompetensi & \multicolumn{1}{c}{ Konten } & Jumlah \\
\hline 1. & Istima' (50) & a. & Pemahaman makna, Penalaran Logis dan \\
& & penyimpulan & 20 item \\
\cline { 3 - 4 } & & b. & Pemahaman Dialog Singkat antar dua orang & 15 Item \\
\cline { 3 - 4 } & & c. & Pemahaman Dialog Panjang antar dua orang atau \\
& & lebih & 15 Item \\
\hline 2. & Tarakib (40) & a. & Melengkapi Ungkapan dan Struktur & 20 Item \\
\cline { 3 - 4 } & & b. & Analisis Penggunaan diksi, Ungkapan dan & 20 Item \\
\hline
\end{tabular}




\begin{tabular}{|c|c|c|}
\hline & Struktur Kalimat & \\
\hline \multirow[t]{4}{*}{ 3. Qira'ah (50) } & c. Taraduf dan Ittidhad & 10 Item \\
\hline & d. I'rab dan Isytiqaq & 10 Item \\
\hline & $\begin{array}{l}\text { e. Pemahaman Makna Tersirat dalam Paragraf } \\
\text { Pendek }\end{array}$ & 15 Item \\
\hline & $\begin{array}{l}\text { f. Pemahaman Makna Tersirat dalam Paragraf } \\
\text { Panjang }\end{array}$ & 15 Item \\
\hline
\end{tabular}

\section{B. Uji Kelayakan Aplikasi CAT-APT}

Produk aplikasi CAT yang dikembangkan pada program APT, wajib dilakukan uji terbatas pada kelompok pengguna (user), validasi oleh ahli materi dan ahli pemrograman. Hasil uji coba dan validasi, terlihat pada deskripsi berikut ini.

\section{Uji Coba Terbatas Kinerja CAT-APT}

Uji coba terbatas penggunaan aplikasi CAT-APT dilakukan untuk mendapatkan respon terhadap produk yang diperoleh dari 20 Mahasiswa PBA. Mereka diminta untuk memberikan penilaian terhadap beberapa aspek yang ditanyakan seperti: tampilan tampilan, cara pengoperasian, isi atau materi, manfaat, dan pengembangan. Hasil respon dari pengguna (user) tersebut dianalisis secara statistik berdasarkan respon kuisioner, seperti pada tabel berikut:

Tabel 6. Uji Coba Terbatas Kinerja CAT-APT

\begin{tabular}{c|l|l|l}
\hline No & \multicolumn{1}{c|}{$\begin{array}{c}\text { Aspek } \\
\text { Penilaian }\end{array}$} & Skor & Interpretasi \\
\hline 1 & Tampilan Aplikasi & $85 \%$ & Sangat Baik \\
\hline 2 & Cara Pengoperasian & $86 \%$ & Sangat Baik \\
\hline 3 & Konten Materi APT & $80 \%$ & Baik \\
\hline 4 & Manfaat & $88 \%$ & Sangat Baik \\
\hline 5 & Pengembangan Produk & $84 \%$ & Sangat Baik \\
\hline
\end{tabular}

Dari lima aspek yang ditanyakan, hanya aspek konten Materi APT yang mendapat skor rata-rata $80 \%$ "Baik" dan empat aspek lainnya yaitu, tampilan, cara pengoperasian, manfaat dan pengembangan mendapat skor rata-rata antara 84\% hingga 88\% "Sangat Baik". Dari respon user tersebut maka pengembangan hybrid leaning berbasis aplikasi CAT, layak digunakan pada program Arabic Proficiency Test (APT). 


\section{Uji Validasi Ahli Media}

Sharon E. Smaldino memperjelas bahwa untuk menilai media pembelajaran yang dikembangkan itu baik atau tidak, dapat diuji dengan pertanyaan-pertanyaan pada aspek-aspek seperti misalnya, kesesuaian dengan materi, kejelasan dan kebenaran materi, kejelasan bahasa, menarik dan memotivasi peserta didik untuk belajar dan sebagainya. ${ }^{25}$. Sedangkan validasi CAT-APT yang dilakukan oleh ahli media menggunakan format penilaian pemilihan media menggunakan checklist terhadap lima aspek yaitu: aspek informasi pendahuluan, cara pengoperasian, konten soal APT, optional jawaban dan system skor dan konversi. Hasil penilaian yang diperoleh dari ahli media pembelajaran diperoleh data nilai skor sebagai berikut:

Tabel 7. Uji Validasi Media CAT-APT

\begin{tabular}{c|l|l|l}
\hline No & \multicolumn{1}{c|}{$\begin{array}{c}\text { Aspek } \\
\text { Penilaian }\end{array}$} & Skor & \multicolumn{1}{|c}{ Interpretasi } \\
\hline 1 & Informasi Pendahuluan & $85 \%$ & Sangat Baik \\
\hline 2 & Cara Pengoperasian & $86 \%$ & Sangat Baik \\
\hline 3 & Konten Soal Istima' & $80 \%$ & Baik \\
\hline 4 & Konten Soal Tarakib & $81 \%$ & Sangat Baik \\
\hline 5 & Konten Soal Qira'ah & $82 \%$ & Sangat Baik \\
\hline 6 & Optional Jawaban & $86 \%$ & Sangat Baik \\
\hline 7 & Sistem Skor dan Konversi & $84 \%$ & Sangat Baik \\
\hline
\end{tabular}

Dari tujuh aspek yang dinilai, aspek konten Istima' yang mendapat skor rata-rata $80 \%$ "Baik" sedangkan pada enam aspek mendapat skor rata-rata antara $81 \%$ hingga $86 \%$ "Sangat Baik".

\section{Uji Validasi Ahli Pemograman}

Uji coba penggunaan CAT-APT yang dilakukan oleh ahli pemrograman menggunakan format penilaian checklist terhadap seluruh menu, sub menu, serta fitur-fitur lainnya, yang terdiri dari empat aspek yaitu aspek : User Interface, Feature Complete, Media Compatibility dan Information System.

Setelah sebuah produk CAT-APT tercipta dengan tampilan yang baik, produk bisa mulai diluncurkan. Namun, sebelum benar-benar diluncurkan ke banyak orang, produk tersebut perlu melakukan proses uji coba dilakukan dengan memberikan skor pada setiap fitur desain. Setelah diuji coba, desain tersebut akan mendapatkan saran dan masukan dari pengguna. Desain kemudian direvisi dan dites kembali sampai menjadi sebuah desain yang nyaman dan diinginkan

${ }^{25}$ Sharon E Smaldino, Deborah L Lowther, and James D Russell, Instructional Technology \& Media for Learning: Teknologi Pembelajaran Dan Media Untuk Belajar (Prenada Media, 2014), 41-42. 
pengguna. Hasil penilaian yang diperoleh dari ahli pemograman diperoleh data nilai skor sebagai berikut:

Tabel 8. Uji Validasi Pemograman CAT-APT

\begin{tabular}{|c|c|c|c|}
\hline No & $\begin{array}{c}\text { Aspek } \\
\text { Penilaian }\end{array}$ & Skor & Interpretasi \\
\hline 1 & \multicolumn{3}{|c|}{ User Interface (User Friendly) } \\
\hline & \multicolumn{2}{|l|}{ a. Kemudahan Program } & Sangat Baik \\
\hline & \multicolumn{2}{|l|}{ b. Kemudahan Menu } & Sangat Baik \\
\hline & \multicolumn{2}{|l|}{ c. Kemudahan Interaksi } & Sangat Baik \\
\hline 2 & \multicolumn{3}{|l|}{ Feature Complete } \\
\hline & \multicolumn{2}{|l|}{ a. Kemudahan Program } & Sangat Baik \\
\hline & \multicolumn{2}{|l|}{ b. Kelangkapan Item APT } & Sangat Baik \\
\hline & c. Nilai Otomatis & $82 \%$ & Sangat Baik \\
\hline & d. Konversi Nilai Otomatis & $82 \%$ & Sangat Baik \\
\hline & e. User Management & $80 \%$ & Baik \\
\hline No & $\begin{array}{c}\text { Aspek } \\
\text { Penilaian }\end{array}$ & Skor & Interpretasi \\
\hline \multirow[t]{5}{*}{3} & \multicolumn{3}{|l|}{ Media Compatibility } \\
\hline & a. Teks & $81 \%$ & Sangat Baik \\
\hline & b. Grafik & $82 \%$ & Sangat Baik \\
\hline & b. Visual Media & $80 \%$ & Baik \\
\hline & c. Visual Audio & $85 \%$ & Sangat Baik \\
\hline 4 & \multicolumn{3}{|l|}{ Information System } \\
\hline & a. Profil Aplikasi & $83 \%$ & Sangat Baik \\
\hline & b. User Manual (Tutorial) & $84 \%$ & Sangat Baik \\
\hline & c. Developer Info & $85 \%$ & Sangat Baik \\
\hline & d. External Links & $87 \%$ & Sangat Baik \\
\hline
\end{tabular}

Dari empat aspek yang dinilai, aspek feature complete pada bagian user management dan media compatibility pada visual media yang mendapat skor rata-rata 80\% "Baik" dan pada aspek user interface dan aspek Information System mendapat skor rata-rata antara 81\% hingga 88\% "Sangat Baik".

\section{Uji Coba Skor CAT-APT pada Tester}

Pengujian hasil digunakan untuk mengetahui kemampuan kerja program CAT-APT dalam memprediksi kemampuan tester melalui butir-butir Arabic Proficiency Test yang dikerjakan. Dalam hal ini program telah diisi basis data bank soal yang dilengkapi dengan beberapa identitas yakni: (1) nomor soal, (2) id soal, (3) nomor pertanyaan dan (4) standar dan indikator soal APT. 
Sebagai bagian dari uji coba aplikasi CAT dalam mengetahui tiga kompetensi Bahasa Arab (istima', tarakib dan qira'ah), maka di samping menguji robustness test (uji ketahanan) seperti munculnya error pada 140 konten soal, peneliti juga melakukan uji coba kepada tester guna mengetahui hasil/skor pada pretest dan posttest. Deskripsi hasil pretest dan prosstes APT sebagaimana pada tabel berikut.

Tabel 9. Hasil Pretest pada Tester

\begin{tabular}{|c|c|c|c|c|c|c|}
\hline \multirow[t]{2}{*}{ No } & \multirow[t]{2}{*}{ Tester } & \multicolumn{3}{|c|}{ Skor } & \multirow[t]{2}{*}{ Pretest } & \multirow[t]{2}{*}{ Konversi } \\
\hline & & Istima' & Tarakib & Qira'ah & & \\
\hline 1 & 181032001 & 38 & 58 & 44 & 140 & 467 \\
\hline 2 & 181032002 & 46 & 53 & 46 & 145 & 483 \\
\hline 3 & 181032004 & 45 & 55 & 43 & 143 & 477 \\
\hline 4 & 181032006 & 45 & 54 & 44 & 143 & 477 \\
\hline 5 & 181032007 & 46 & 54 & 41 & 141 & 470 \\
\hline 6 & 181032008 & 48 & 51 & 42 & 141 & 470 \\
\hline 7 & 181032020 & 46 & 46 & 48 & 140 & 467 \\
\hline 8 & 181032021 & 48 & 55 & 39 & 142 & 473 \\
\hline 9 & 181032022 & 32 & 51 & 35 & 118 & 393 \\
\hline 10 & 181032023 & 32 & 46 & 42 & 120 & 400 \\
\hline \multirow[t]{2}{*}{ No } & \multirow[t]{2}{*}{ Tester } & \multicolumn{3}{|c|}{ Skor } & \multirow[t]{2}{*}{ Pretest } & \multirow[t]{2}{*}{ Konversi } \\
\hline & & Istima' & Tarakib & Qira'ah & & \\
\hline 11 & 181032024 & 41 & 41 & 48 & 130 & 433 \\
\hline 12 & 181032025 & 48 & 43 & 50 & 141 & 470 \\
\hline 13 & 181032028 & 44 & 53 & 46 & 143 & 477 \\
\hline 14 & 181032031 & 43 & 58 & 40 & 141 & 470 \\
\hline 15 & 181032032 & 45 & 44 & 44 & 133 & 443 \\
\hline 16 & 181032033 & 51 & 37 & 44 & 132 & 440 \\
\hline 17 & 181032037 & 50 & 53 & 52 & 155 & 517 \\
\hline 18 & 181032040 & 46 & 54 & 34 & 134 & 447 \\
\hline 19 & 181032041 & 48 & 55 & 44 & 147 & 490 \\
\hline 20 & 181032025 & 49 & 58 & 46 & 153 & 510 \\
\hline
\end{tabular}

Hasil uji coba sebanyak tiga kali diperoleh skor rata-rata pretest dengan klasifikasi sebagai berikut: a) Elementary (310-420) sebanyak 2 tester, b) Low Intermediate (421-480) sebanyak 14 tester, c) High Intermediate (481-520) sebanyak 4 tester, dan d) Advance (482-677) tidak ada. 
Tabel 10. Hasil Posttest pada Tester

\begin{tabular}{|c|c|c|c|c|c|c|}
\hline \multirow[t]{2}{*}{ No } & \multirow[t]{2}{*}{ Tester } & \multicolumn{3}{|c|}{ Skor } & \multirow[t]{2}{*}{ Posttest } & \multirow[t]{2}{*}{ Konversi } \\
\hline & & Istima' & Tarakib & Qira'ah & & \\
\hline 1 & 181032001 & 52 & 56 & 52 & 160 & 533 \\
\hline 2 & 181032002 & 52 & 58 & 53 & 163 & 543 \\
\hline 3 & 181032004 & 57 & 55 & 58 & 170 & 567 \\
\hline 4 & 181032006 & 58 & 54 & 60 & 172 & 573 \\
\hline 5 & 181032007 & 59 & 54 & 56 & 169 & 563 \\
\hline 6 & 181032008 & 54 & 51 & 57 & 162 & 540 \\
\hline 7 & 181032020 & 52 & 46 & 55 & 153 & 510 \\
\hline 8 & 181032021 & 54 & 55 & 47 & 156 & 520 \\
\hline 9 & 181032022 & 43 & 51 & 44 & 138 & 460 \\
\hline 10 & 181032023 & 44 & 46 & 57 & 147 & 490 \\
\hline 11 & 181032024 & 48 & 41 & 55 & 144 & 480 \\
\hline 12 & 181032025 & 54 & 43 & 58 & 155 & 517 \\
\hline 13 & 181032028 & 50 & 53 & 53 & 156 & 520 \\
\hline 14 & 181032031 & 49 & 56 & 48 & 153 & 510 \\
\hline 15 & 181032032 & 51 & 44 & 52 & 147 & 490 \\
\hline 16 & 181032033 & 58 & 37 & 52 & 147 & 490 \\
\hline 17 & 181032037 & 57 & 53 & 52 & 162 & 540 \\
\hline 18 & 181032040 & 52 & 54 & 51 & 157 & 523 \\
\hline 19 & 181032041 & 54 & 55 & 52 & 161 & 537 \\
\hline 20 & 181032025 & 55 & 56 & 37 & 148 & 493 \\
\hline
\end{tabular}

Hasil uji coba terakhir diperoleh skor posttest dengan klasifikasi sebagai berikut: a) Elementary (310-420) tidak ada, b) Low Intemediate (421-480) sebanyak 2 tester, c) High Intermediate (481-520) sebanyak 9 tester, dan d) Advance (482-677) 9 tester.

Berdasar hasil analisis data dari ke-20 Mahasiwa menunjukkan bahwa hybrid leaning berbasis aplikasi CAT-APT,yang dikembangkan berdasarkan kebutuhan pengguna, lembaga dan pengadabtasian tes bahasa Arab ke dalam sebuah program, maka dapat dipastikan bahwa aplikasi ini berhasil dengan baik, tepat, akurat, mudah dioperasikan, bermanfaat bagi pengguna, serta hasil akhir sesuai yang diinginkan (expected results) dan program dinyatakan berhasil (pass). 


\section{KESIMPULAN}

Pengembangan Hybrid Learning berbasis aplikasi CAT dapat digunakan dan compatible pada program Arabic Proficiency Test, yang memenuhi beberapa aspek 1) Self Instructional (dapat secara mandiri), 2) Self Instructional ( sesuai kebutuhan) 3) Self Contained), 4) Standalone (dapat dioperasikan secara independen), dan 5) User Friendly (mudah dioperasikan), serta 6) Adaptif terhadap perkembangan teknologi.

Hasil uji coba CAT-APT pada kelompok terbatas diperoleh skor 80 (baik) s/d 88 (sangat baik), pada uji validasi media diperoleh skor 80 (baik) s/d 86 (sangat baik), uji validasi pemograman dengan skor 80 (baik) s/d 88 (sangat baik), sedangkan uji coba skor pada tester, skor pretest belum sampai ke tingkat advance, sedangkan pada posttest diperoleh 9 tester yang mencapai skor Advance.

Dalam penelitian ini uji coba aplikasi CAT-APT secara umum berjalan baik mulai entri, bank soal dan data master, informasi skor dan konversi dapat diperoleh secara langsung setelah ujian selesai, sehingga aplikasi ini dipandang aman, praktis dan mudah dalam pelaksanaan tes bahasa Arab serta dapat dikembangkan lagi pada model-model tes lainnya, seperti tes pemerolehan atau tes prestasi (achievement test, al-ikhtibar al-tahshili), tes kesiapan berbahasa (language aptitude test, ikhtibar al-isti'dad al-lughawi) atau tes prediksi (predictive test, al-ikhtibâr al-tanabbui). Implikasi penelitian ini adalah bahwa pengembangan Hybrid Learning berbasis CAT pada tes Bahasa harus didukung hardware standar sehingga software pendukung tes dapat berjalan dengan baik. Apliaksi CAT-APT ke depan perlu dikembangkan lagi dengan model tes bahasa Arab interaktif (ikhtibar tafa"uli) yang diperuntukkan untuk maharah al-Kalam, karena model tersebut didiakomodir oleh tes APT dan TOAFL.

\section{DAFTAR PUSTAKA}

Ahmad Syamsul Ma'arif. "Sighah Ikhtibarat Al-'Arabiyyah Fi Dui Al-Ikhtibar Al-Mutqn (TOAFL)." Jurnal Al Bayan 9, no. 2 (2017): 161-73. https://doi.org/https://doi.org/10.24042/albayan.v9i2.2233.

Ahsanuddin, Mohammad. "Jurusan Sastra Arab Fakultas Sastra." In Prosiding KONASBARA, 304-9. Mal: KONASBARA, 2016.

Bahari, Akbar. "Computer-Assisted Language Proficiency Assessment Tools and Strategies." Open Learning: The Journal of Open, Distance and e-Learning, 2020, 1-27.

Buska, Wahyudi, Yogia Prihartini, and Nur Hasnah. "Analysis of Students' Arabic Proficiency for Vocabulary Mastery in State Islamic Junior High School in Muaro Jambi." INNOVATIO: Journal for Religious Innovation Studies 18, no. 1 (2018): 51-62. https://doi.org/10.30631/innovatio.v18i1.40. 
Gall, Meredith Damien, Walter R Borg, and Joyce P Gall. Educational Research: An Introduction. Longman Publishing, 1996.

Hediansah, Disa, and Herman Surjono. "Hybrid Learning Development to Improve Teacher Learning Management." JKTP: Jurnal Kajian Teknologi $\begin{array}{lllll}\text { Pendidikan } & 3, & \text { no. } & 1 & \text { (2020): }\end{array}$ https://doi.org/10.17977/um038v3i12019p001.

Hula, Ibnu Rawandhy N. "Preferensi Abu Dawud Sulaiman Bin Najjah Dalam Kaidah Rasm Al-Mushaf/Preference of Abu Dawud Sulaiman Bin Najjah In Rules of Rasm Al-Mushaf." Diwan: Jurnal Bahasa Dan Sastra Arab 6, no. 2 (2020). https://doi.org/https://doi.org/10.24252/diwan.v6i2.13969.

Hula, Ibnu Rawandhy N, Berti Arsyad, Iain Sultan, Amai Gorontalo, and Universitas Muhammadiyah Gorontalo. "Diakritik Al-Quran Menurut Preferensi Abu Dawud." 'A Jamiy: Jurnal Bahasa Dan Sastra Arab 9, no. 2 (2020): 265-84. https://doi.org/http://dx.doi.org/10.31314/ajamiy.9.2.264284.2020 .

Khotimah, Khusnul. "Pengembangan Prototipe Computer Assisted Test (Cat) Menggunakan Arsitektur Model View Controller Pada Badan Kepegawaian Negara." Jurnal Teknologi 8, no. 2 (2016): 53. https://doi.org/10.24853/jurtek.8.2.53-60.

Luther, Arch C. Authoring Interactive Multimedia. Academic Press Professional, Inc., 1994.

Muhajir, Mohamad, and Mohamad Naim Madjid. "The Importance of TOAFL in Improving the Language Skills of Arabic Language Education of Sixth Semester Students at Universitas Muhammadiyah Yogyakarta" 518, no. ICoSIHESS 2020 (2021): 253-57. https://doi.org/10.2991/assehr.k.210120.132.

Nihad, El Ghouch, Kouissi Mohamed, and En Naimi El Mokhtar. "Designing and Modeling of a Multi-Agent Adaptive Learning System (MAALS) Using Incremental Hybrid Case-Based Reasoning (IHCBR).” International Journal of Electrical and Computer Engineering 10, no. 2 (2020): 1980-92. https://doi.org/10.11591/ijece.v10i2.pp1980-1992.

PD-Dikti. "Data Mahasiswa Berdasarkan Pelaporan Aktifitas Mahasiswa Pada Tahun Ajaran Tersebut. Jika Tidak Sesuai, Perguruan Tinggi Diwajibkan Memperbaiki Pelaporannya Melalui Aplikasi PDDikti Feeder." Pangkalan Data Pendidikan TInggi, 2020.https://pddikti.kemdikbud.go.id/data_pt/QUJGOURBNEQtNUUyRS00 MDg1LUIzODMtQjY4QzdBNDIDM0VG.

Piskurich, George M. Rapid Instructional Design. Wiley Online Library, 2015. 
Qodri, Muhammad. "Arabic Language Test in the Perspective of CompetencyBased Curriculum for Students of Madrasah Aliyah Negeri 3 Malang” 2, no. 2 (2019): 115-34. https://doi.org/https://doi.org/10.22219/jiz.v2i2.10003.

Rabiah, Sitti. "Penggunaan Metode Research and Development Dalam Penelitian Bahasa Indonesia Di Perguruan Tinggi," 2018.

Rahardi, Fauzi Hafizh, Andi Bayu Daffa, Tandri Ajeng, and Maudi Yuningsih Partotaruno. "Spoil System Sebagai Tantangan Penyelenggaraan Pemerintahan Di Era Digitalisasi." Prosiding Simposium Nasional "Tantangan Penyelenggaraan Pemerintahan Di Era Revolusi Indusri 4.O" 0, no. $001378-1401$. https://doi.org/https://doi.org/10.22219/PSNIP.Vol0.No0.II|1378-1401.

Rahardian, Riekko Rahmat, Retno Indah Rokhmawati, and Komang Candra Brata. "Perancangan User Experience Aplikasi Computer Assisted Test ( CAT ) Berbasis Website Menggunakan Metode Goal-Directed Design Pada Badan Kepegawaian Daerah Kabupaten Lumajang." Jurnal Pengembangan Teknologi Informasi Dan Ilmu Komputer 3, no. 7 (2019): 6486-94.

Ridho, Ubaid. "Evaluasi Dalam Pembelajaran Bahasa Arab." An Nabighoh Jurnal Pendidikan Dan Pembelajaran Bahasa Arab 20, no. 01 (2018): 19. https://doi.org/10.32332/an-nabighoh.v20i01.1124.

Sinaga, Jona Bungaran Basuki. "Opini Peserta Seleksi Calon Aparatur Sipil

Negara Terhadap Sistem Computer Assited Test (CAT)." MSDA, Manajemen Sumber Daya Aparatur 3, no. 1 (2019): 63-76. https://doi.org/https://doi.org/10.33701/jmsda.v7i1.1143.

Smaldino, Sharon E, Deborah L Lowther, and James D Russell. Instructional Technology \& Media for Learning: Teknologi Pembelajaran Dan Media Untuk Belajar. Prenada Media, 2014.

Toifah, Nur. Evaluasi Dan Statistika Pembelajaran Bahasa Arab. Literasi Nusantara. 1st ed. Vol. 53. Malang: Literasi Nusantara, 2019.

Vanpee, Katrien, and Dan Soneson. "Arabic Proficiency Improvement Through a Culture of Assessment." In Foreign Language Proficiency in Higher Education, 197-216. Springer, 2019.

Wahab, Muhbib Abdul. "Pengembangan Tes Bahasa Arab Standar Di Indonesia." Journal of Chemical Information and Modeling 53, no. 9 (2013): 1689-99.

Wang, Xiaoyue, Han Sun, and Lixin Li. "An Innovative Preschool Education Method Based on Computer Multimedia Technology." International Journal of Emerging Technologies in Learning 14, no. 14 (2019): 57-68. https://doi.org/10.3991/ijet.v14i14.10714. 